the lighting industry started in 1903 at the National Physical Laboratory, where he was largely responsible for the design and calibration of the electric lamps which formed the standard of luminous intensity until 1948. Sir Clifford was, for a number of years, the director of the Research Laboratories of the General Electric Co., Ltd, and although his interests extended over many fields, it was in the subjects of photometry and illumination that he was peculiarly interested. He was one of the founders of the International Commission on Illumination and was its honotaty secretary for many years.

\section{Middle East Oil}

IN an article. in $\%$ olume 31 , No. 1, of The Lamp (house journal the Standard Oil Co., New Jersey, published fiftimes a year primarily for employees and stod 4 olders) a survey is made of progress in oil prodyctioh during the past fifty years in the Middle East. Turing that time production increased systematicdlly, until in 1948 it reached a total of one million gallons per day, and the area became recognized as the third most important producing centre of the world, the United States and the Caribbean being first and second respectively. The most significant oil region in the Middle East as yet discovered lies in a great geological trough which extends through Iran, Iraq, Saudi Arabia and the smaller sheikhdoms of Kuwait, Bahrein and Quatar. There is intense activity throughout the area, and the very great rise in production is a measure of the success of prolonged labour by oilmen in one of the hottest climates of the world. Nevertheless, Middle East oil could be made to flow faster by elimination of the present bottleneck in transportation. Ninety per cent of the oil is concentrated in the Persian Gulf area, which at the nearest point lies eight hundred miles east and southeast of the Mediterranean. Every barrel of oil travels by sea. The route will probably remain the same for destinations east of Suez; but for the great markets of Western Europe, substitution of overland pipeline transport is geographically feasible. A combined land and sea route of four thousand one hundred miles to the English Channel ports compares impressively with the present all-sea route from the Persian Gulf, south-east round Arabia and northwards through the Red Sea and the Suez Canal. Pipelines when built will, it is estimated, eliminate more than three thousand one hundred miles of tanker haulage on shipments to Western Europe. A map showing proposed pipelines in the Middle East clearly indicates the extent of the project and at the same time demonstrates the present formidable wastage of tanker haulage. Given adequate overland transport facilities, this region can meet all Western European requirements. At the same time, the peoples of the Middle East will begin to feel the benefits attendant upon development of the first mass-volume export complpdity they have ever.had.

Bird Photc

A мEтHOD taking bird photographs which promises to bo great value in the analysis and understandidg of bird flight has been described by Eric Hoskikg (British Birds, 42, No. 8; August 1949) two high-speed electronic flash is many times brigl fer than bright sunlight and is usually arranged to last about $1 / 10,000$ second. 'The set built to produce the flash was made by Dr. P. S. H. Henry, who also devised a photo-cell trip that would automatically operate the camera shutter, and with it the flash, at the instant the bird passed through a pre-arranged zone in front of the camera. With this ingenious apparatus the bird thus takes its own photograph at the moment that it is itself in focus. Mr. Hosking illustrates his article with a number of photographs which have been taken by high-speed electronic flash and suggests that here may well be a means of advancing the study of aeronautics. This new method of photography should certainly add to our knowledge of bird life, and particularly of the more active phases of bird behaviour like courtship and aggressive displays, as well as the identification of food carried in the bill and the recording of feeding behaviour at the nest.

\section{Sources of Information in Great Britain}<smiles>C1=CCCCC1</smiles>

ThE first two ofa series of "Aslib Guides to Sources of Informatipy in Great Britain", issued in pamphlet form suitabl for inclusion in a loose-leaf binder, and intend of cufulatively to form a new edition of the "A Sib Wirectory", have recently been published (No. 1, (T) Paper Industry; pp. ii $+14 ; 2 s .6 d$. net, to mddbers, 2s. No. 2, Agriculture and Allied Interests ; pp. $\mathrm{v}+64 ; 16 s$. net, to members, 13s.). The pamphlets are numbered in accordance with the Universal Decimal Classification and are arranged in three sections dealing with relevant national libraries and loan services, with the organisations in Great Britain which are the main sources of information in the particular field, and with the publications, including periodicals, directories, annuals and yearbooks. They are provided with a subject index to the libraries and other organisations and to the publications listed.

\section{Agricultural Attache to the British Embassy in Buenos Aires}

Mr. A. G.MrLL has been appointed to succeed Major T. A. Rattray as agricultural attaché to the British Embassy in Buenos Aires. Mr. Mill, who is forty-one, has been connected with farming all his life, mainly with cattle, sheep and horses. From 1928 he was for ton years in the Argentine as an estate manager for Liebig's Extract of Meat Co. During the Second World War he was a government livestock officer in Britain, and since 1945 he has served in that capacity in Barbados.

\section{Colonial Service : Recent Appointments}

THe following appointments in the Colonial Service have been recently announced : D. J. O. Burke, A. G. Cullum and A. A. Kingshotte, agricultural officers, Nigerja; I. Constantinesco and A. Hamersley, agricult/ral officers, Tanganyika; J. H. Rhodes and A.T. Wilson, agricultural officers, Northern Rhodesia ; J. Evans and J. A. Sandys, agricultural officers, Nyasaland ; D. W. M. Haynes, agricultural officer, Federation of Malaya; R. H. Forster, agricultural officer, North Borneo; H. Sandford, agricultural officer, Sarawak; E. F. H. Sturgeon, agricultural officer (for soil conservation), Nyasaland; A. G. Bramwell, J. L. Masson, A. J. L. Mitchell and A. L. Roxburgh, assistant conservators of forests, Nigeria; A. P. B. Hamilton, assistant conservator of forests, Northern Rhodesia/Nyasaland; J. R. Hilton, assistant conservator of forests, Uganda; C. S. Kilpatrick, assistant conservator of forests, British Guiana; A. N. Loweth, assistant conservator of forests, Fiji ; I. Paul, assistant conservator of forests, Sierra Leone; M. G. Yearsley, assistant conservator of forests, Gold Coast; O. P. Casey, G. C. McCallum 